Jurnal Bimas Islam Vol 14 No. 2

Website: jurnalbimasislam.kemenag.go.id/index.php/jbi

ISSN 2657-1188 (online) ISSN 1978-9009 (print)

\title{
Optimalisasi Wakaf sebagai Instrumen Pembiayaan UMKM untuk Pengembangan Industri Halal
}

\section{The Optimization of Waqf as a MSME Financing Instrument for the Halal Industry Development}

\author{
Ade Nur Rohim \\ Universitas Pembangunan Nasional Veteran Jakarta \\ email: adenurrohim@upnvj.ac.id
}

Artikel diterima 26 Agustus 2021, diseleksi 20 September 2021

dan disetujui 20 Desember 2021

Abstrak: Permodalan masih menjadipermasalahan utama yang dihadapipelaku UMKM khususnya di masa pandemi seperti saat ini. Sebagai salah satu instrumen keuangan Islam, wakaf dapat berkontribusi langsung dalam mengembangkan UMKM melalui skema pembiayaan yang bertujuan untuk mensejahterakan umat. Artikel ini bertujuan untuk mengelaborasi dan mendalami optimalisasi wakaf sebagai instrumen pembiayaan alternatif bagi UMKM yang sesuai dengan prinsip syariah dan kehalalan. Hal kebaruan yang diangkat dalam penelitian ini adalah telaah spesifik terkait pemberdayaan wakaf untuk pengembangan industri halal di sektor UMKM. Kajian ini menggunakan metode kualitatif dengan pendekatan studi pustaka, dengan melakukan analisis konten secara deskriptif dan merujuk kepada literatur yang berkaitan dengan UMKM dan wakaf. Hasil penelitian menunjukkan bahwa wakaf dan UMKM memiliki keterkaitan yang sangat erat dalam upaya mewujudkan kesejahteraan masyarakat. Optimalisasi wakaf sebagai salah satu sumber pembiayaan alternatifbagi UMKM dilakukan melaluipola penyaluran manfaat wakaf maupun dengan penyaluran aset wakaf dalam bentuk wakaf tunai. Skema penyaluran tersebut dilakukan dengan tetap memperhatikan aspek kehalalan usaha yang dijalani, serta akad yang sesuai dengan prinsip syariah. 
Optimalisasi wakaf melalui skema pembiayaan dan pendayagunaannya, diharapkan dapat berimplikasi langsung pada pengembangan industri halal, yang bertujuan untuk mewujudkan kesejahteraan masyarakat.

Kata Kunci: wakaf; pembiayaan; UMKM; industri halal.

Abstract :Capital is still the main problem faced by MSME actors, especially during the current pandemic. As one of the Islamic financial instruments, waqf can contribute directly to develop MSME through financing schemes that aims to improve the welfare of the community. This article aims to elaborate and explore the optimization of waqf as an alternative financing instrument for MSME in accordance with sharia and halal principles. The novelty raised in this study is a specific study related to the waqf empowerment for the halal industry development in the MSME sector. This study uses a qualitative method with a literature study approach, by conducting a descriptive content analysis and referring to the literature related to MSME and waqf. The results of this study indicate that waqf and MSME have a very close relationship in an effort to realize the welfare of the community. The optimization of waqf as an alternative MSME financing source is carried out through the waqf benefits distribution form as well as the waqf assets distribution in the cash waqf form. The distribution scheme is carried out by taking into account the halal aspects of the business being undertaken, as well as contracts that are in accordance with sharia principles. The optimization of waqf through the financing schemes and the utilization is expected to have direct implications for the halal industry development, which aims to realize the welfare of the community.

Keywords: waqf; financing; MSME; halal industry 


\section{A. Pendahuluan}

Usaha Mikro, Kecil, dan Menengah (UMKM) merupakan salah unit ekonomi yang berperan penting dalam perekonomian Indonesia. Sektor UMK saja (non usaha menengah) telah menyerap 75,33 persen dari total tenaga kerja non pertanian, serta menyumbang sebanyak 60,34 persen dari total PDB nasional. Bahkan ketika terjadi krisis ekonomi di tahun 1998, UMK tetap mampu berdiri kokoh, di saat usaha besar berjatuhan. ${ }^{1}$ Kontribusi positif dan kekuatan yang dimiliki UMKM mendorong peningkatan jumlah UMKM yang selalu meningkat di tiap tahunnya. Pada tahun 2018, Kementerian Koperasi dan UKM mencatat sedikitnya terdapat 64,2 juta UMKM di Indonesia. ${ }^{2}$ Jumlah yang cukup besar untuk menyokong pergerakan roda perekonomian nasional, jika dikelola secara optimal

Banyaknya jumlah UMKM yang ada masih menyisakan persoalan yang dihadapi oleh para pelaku UMKM. Di balik besarnya jumlah pelaku UMKM, tidak sedikit dari mereka yang menghadapi kendala dan keterbatasan. Beberapa kendala yang dihadapi antara lain akses perbankan, manajemen SDM, hingga infrastruktur pendukung. Hal yang paling umum adalah kendala terkait permodalan dan keterbatasan akses keuangan untuk pengembangan usahanya. ${ }^{3}$ Kondisi ini tentu menjadi salah satu faktor terhambatnya perkembangan UMKM untuk bersaing di level nasional ataupun internasional. Diperlukan akses permodalan alternatif untuk dapat mengatasi permasalahan tersebut, sehingga peran UMKM sebagai penopang kesejahteraan masyarakat dapat lebih dioptimalkan.

Kesejahteraan masyarakat direalisasikan melalui optimalisasi berbagai sumber daya dan instrumen. Salah satu instrumen ekonomi Islam yang berfungsi untuk mendorong kesejahteraan masyarakat adalah wakaf. Fungsi tersebut dibuktikan berdasarkan pengalaman di beberapa negara yang menunjukkan signifikansi peran wakaf dalam mewujudkan kesejahteraan dan kemandirian ekonomi masyarakat. 
Sebagaimana keberhasilan Mesir dalam mengelola wakaf secara profesional, khususnya di bidang properti, pertanian, dan reklamasi tanah. Bahkan Amerika Serikat berhasil mengoptimalkan pengelolaan wakaf di bawah pengelolaan Kuwait Awqaf Public Foundation (KAPF). Aset wakaf produktif yang dimiliki berupa proyek apartemen senilai \$85 juta di atas tanah yang dimiliki oleh the Islamic Cultural Center of New York. ${ }^{4}$ Keberhasilan ini menekankan urgensi wakaf sebagai instrumen pembangunan ekonomi Islam. Keberhasilan yang ditunjukkan negara lain, tentu juga berbanding lurus dengan potensi Indonesia dalam optimalisasi wakaf.

Sebagai negara dengan mayoritas penduduk muslim, Indonesia memiliki potensi pengembangan wakaf yang sangat besar. ${ }^{5}$ Kementerian Agama mencatat jumlah tanah wakaf di Indonesia tercatat seluas 51.709,07 hektar yang tersebar di 383.333 lokasi. ${ }^{6}$ Secara umum, pemanfaatan tanah wakaf banyak didominasi untuk beberapa objek wakaf, seperti masjid, mushalla, makam, dan sarana pendidikan atau sekolah. Gambar 1. menunjukkan bahwa pemanfaatan tanah wakaf untuk masjid mencapai 44,34 persen, sedangkan mushala mencapai 28,41 persen. Selain itu, tanah wakaf juga dimanfaatkan untuk sekolah yang mencapai 10,68 persen. Berdasarkan data tersebut, diketahui bahwa lebih dari separuh total tanah wakaf dimanfaatkan untuk masjid dan mushala. Meski demikian, jumlah tanah wakaf yang besar tentu sangatlah potensial untuk dikembangkan secara produktif. Untuk itu, diperlukan pengelolaan aset wakaf secara profesional agar dapat memberikan manfaat yang lebih luas bagi masyarakat. 


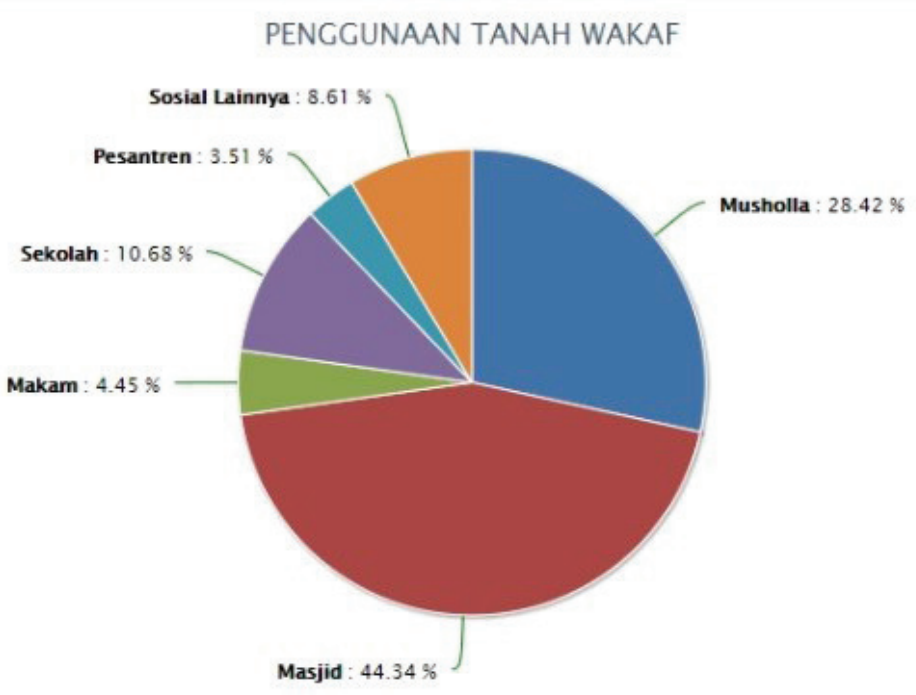

Gambar 1. Pemanfaatan Tanah Wakaf

Sumber: Sistem Informasi Wakaf (Siwak), 2020

Saat ini pengelolaan wakaf telah mengalami perkembangan yang signifikan, salah satunya melalui instrumen wakaf uang. Undangundang No. 41 Tahun 2004 tentang Wakaf telah menjelaskan secara spesifik ketentuan terkait wakaf uang. Sebelumnya, MUI juga telah mengeluarkan Fatwa MUI No. 2 Tahun 2002 tentang Wakaf Uang. Kedua regulasi tersebut menjadi pijakan dalam upaya mengembangkan dan mengenalkan wakaf uang di Indonesia kepada masyarakat. Melalui instrumen wakaf uang, masyarakat dapat mulai berwakaf dengan nilai harta yang relatif tidak terlalu besar. Hal ini berdampak positif pada pemberian kesempatan bagi masyarakat yang lebih luas untuk berwakaf, serta meningkatkan produktivitas wakaf.

Upaya untuk mengembangkan produktivitas aset wakaf terus dilakukan, termasuk dengan pemanfaatan wakaf tunai yang lebih fleksibel untuk meningkatkan produktivitas. Selain itu, langkah tersebut juga diharapkan dapat mendorong peningkatan kesejahteraan masyarakat yang bermuara pada pertumbuhan ekonomi. Hal tersebut 
ditunjukkan salah satunya seperti program CWLS Ritel yang diluncurkan untuk mendukung Gerakan Wakaf Nasional. ${ }^{7}$ Untuk mewujudkan hal tersebut, dibutuhkan upaya mendorong sektor rill yang lebih intensif. Hal tersebut lantaran sektor riil memainkan peran yang sangat vital dalam perputaran ekonomi, dari kegiatan produksi dan konsumsi. Sektor riil tersebut mencakup semua tingkat dan skala usaha, mulai dari usaha mikro, kecil, menengah, hingga skala besar.

Kontribusi UMKM terhadap pertumbuhan ekonomi menjadikan UMKM sebagai sektor yang sangat layak dan perlu untuk dikembangkan. Dengan kekuatan landasan kultur dan kedaerahan yang dimiliki, UMKM berpotensi tinggi dalam mendorong peningkatan produksi berbasis lokal daerah. Jika merujuk kepada jumlah penduduk muslim yang besar, Indonesia merupakan pasar yang sangat besar untuk produk halal. ${ }^{8}$ Hal ini menjadikan UMKM sangat potensial dalam mendorong peningkatan produk-produk halal berbasis lokal kedaerahan. Kendati demikian, upaya mengatasi berbagai kendala yang dihadapi UMKM masih menjadi agenda besar, termasuk dalam hal permodalan. Kendala ini menyebabkan pelambatan dalam pengembangan produksi halal oleh UMKM. Untuk itu, diperlukan optimalisasi wakaf produktif dalam pemberdayaan UMKM untuk meningkatkan produksi halal.

Penelitian terkait pemberdayaan wakaf telah banyak dilakukan. Di antaranya penelitian oleh Hadyantari yang menemukan bahwa pemberdayaan wakaf dilakukan dengan menyalurkan manfaat dan hasil pengelolaan wakaf produktif, baik berupa tanah maupun uang. Target dari pemberdayaan tersebut adalah untuk mewujudkan kesejahteraan ekonomi masyarakat. ${ }^{9}$ Lebih lanjut, Yuli yang melakukan penelitian dengan judul Optimalisasi Peran Wakaf dalam Pemberdayaan Usaha Mikro, Kecil dan Menengah (UMKM) menyimpulkan bahwa optimalisasi wakaf produktif untuk UMKM sejatinya dapat dilakukan melalui pemberian modal investasi maupun modal kerja. Selain itu, nazhir wakaf juga perlu memberikan pelatihan, pendampingan, dan peningkatan keterampilan untuk meningkatkan produktivitas UMKM. ${ }^{10}$ Dalam topik yang sejenis, 
Nurdianto meneliti pada aspek pengembangan teknologi bagi UMKM. Program yang dapat diterapkan adalah dengan membantu membuat website marketplace bagi para pelaku UMKM. Selain itu, pendampingan dan pelatihan manajemen bisnis UMKM juga sangat mutlak diperlukan, khususnya kepada inkubator bisnis. ${ }^{11}$ Kendati demikian pemberdayaan UMKM melalui instrumen wakaf belum menjadikannya sebagai target secara spesifik, khususnya pada sektor pengembangan industri halal. Padahal nilai dan ketentuan Islam yang termuat dalam wakaf sangat relevan dengan upaya pengembangan produksi halal, khususnya dari sektor UMKM.

Artikel ini akan menitikberatkan pada optimalisasi pemberdayaan wakaf kepada sektor UMKM sebagai produsen halal. Di samping itu, artikel ini juga akan mengkaji pola pemberdayaan wakaf kepada produksi halal melalui sektor UMKM dengan skema pembiayaan yang sesuai dengan prinsip syariah, sehingga kesejahteraan ekonomi umat sebagai target wakaf maupun UMKM akan terwujud.

Kajian ini menggunakan metode kualitatif dengan pendekatan studi pustaka dengan metode analisis konten. Studi pustaka dilakukan dengan mengkaji dan menelaah berbagai literatur dan kebijakan terkait konsep dan optimalisasi instrumen wakaf sebagai bagian dari keuangan sosial Islam. Hasil telaah dianalisis secara deskriptif dengan mengelaborasi konsep dan implementasi pengelolaan wakaf pada pola pembiayaan usaha dengan mengacu kepada ketentuan hukum dan regulasi terkait. Kajian wakaf diarahkan pada optimalisasi fungsi dan pemanfaatannya pada pemberdayaan UMKM, sebagai alternatif solusi dalam mengatasi permodalan bagi pelaku UMKM dan pengembangan industri halal.

\section{B. Hasil dan Pembahasan}

\section{Wakaf: Konsep dan Potensinya di Indonesia}

Wakaf merupakan istilah dari bahasa Arab al-waqfu. Secara etimologis wakaf berarti al-habsu yang dalam bahasa Indonesia berarti menahan atau 
diam pada tempat atau menghentikan sesuatu. ${ }^{12}$ Secara terminologis, Ahmad Muhammad dalam kitab Daur Nizam al-Waqf al-Islamiy fi atTanmiyah al-Iqtishadiyyah al-Mu'ashirah menjelaskan bahwa wakaf bearti menahan asalnya, dan menyalurkan manfaatnya kepada kebaikan atau kepada kegiatan yang ditunjukan untuk mendekatkan kepada Allah swt. ${ }^{13}$ Adapun secara 'urf, Imam Abdurrauf bin Tajuddin dalam Kitab Taysir al-Wuquf menjelaskan bahwa wakaf merupakan kegiatan menahan sesuatu yang tidak mungkin dimanfaatkan dengan menjaga fisik barang atau wujudnya, namun tetap dilakukan transaksi atau perlakuan atas barang tersebut untuk dimanfaatkan dalam hal kebaikan yang diniatkan untuk mendekatkan kepada Allah swt. ${ }^{14}$

Secara garis besar, ulama mengklasifikasikan wakaf ke dalam dua jenis, yaitu wakaf khairi dan wakaf dzurri. Wakaf khairi merupakan wakaf yang bersifat filantropis yang ditujukan untuk maslahat dan kebaikan umat yang lebih umum, seperti bantuan bagi fakir miskin, anak yatim, dan lainnya. Lebih dari itu, wakaf khairi juga dapat dimanfaatkan bagi pembangunan fasilitas publik seperti fasilitas kesehatan, pendidikan, atau pun layanan publik lainnya. Sementara wakaf dzurri merupakan wakaf yang ditujukan untuk disalurkan kepada anak dan keturunannya, maupun kerabatnya.

Saat ini Indonesia memiliki potensi wakaf yang sangat besar. Untuk aset wakaf berupa harta tidak bergerak, Kementerian Agama mencatat luas tanah wakaf di Indonesia seluas 52.180,09 hektar. Dari total luas tanah tersebut, tanah wakaf terbagi menjadi tanah wakaf yang bersertifikat seluas 19.690,44 hektar, dan tanah yang belum bersertifikat seluas $32.489,65$ hektar. ${ }^{15}$ Bahkan Nizar dalam penelitiannya menemukan hasil kajian bahwa Indonesia merupakan negara yang memiliki harta wakaf paling luas di dunia, terutama tanah yaitu sekitar 440.512, 89 hektar. ${ }^{16}$

Selain aset dalam bentuk tanah, wakaf juga saat ini dikembangkan dalam bentuk uang, atau yang umum disebut dengan wakaf tunai atau wakaf uang. Perkembangan wakaf tunai di Indonesia, semakin 
mengalami peningkatan yang signifikan. Badan Wakaf Indonesia (BWI) menyebutkan jumlah potensi wakaf tunai mencapai Rp188 triliun per tahun. Meski begitu realisasi penerimaan wakaf tunai baru mencapai Rp400 miliar. ${ }^{17}$

Potensi wakaf yang besar tentu sangat berpengaruh positif kepada peningkatan kesejahteraan umat. Karena sesuai dengan tujuan dari wakaf adalah sebagai instrumen peningkatan kesejahteraan umat dan mengatasi kesenjangan ekonomi di masyarakat. Sehingga upaya mendorong pengembangan wakaf sejatinya merupakan upaya dalam mengatasi permasalahan sosial ekonomi di masyarakat.

\section{Prospek Perkembangan Industri Halal}

Indonesia merupakan negara dengan populasi muslim terbesar di dunia. Hal ini menjadikan Indonesia sebagai pasar besar bagi industri halal. Sehingga diperlukan peningkatan produksi halal dalam jumlah yang besar, untuk memenuhi kebutuhan masyarakat di Indonesia. Permintaan atau demand terhadap produk halal akan meningkat signifikan. Untuk itu diperlukan suatu upaya komprehensif untuk meningkatkan dan mengembangkan industri halal di Indonesia yang memiliki pasar yang besar.

Indonesia menjadi salah satu negara yang diproyeksikan akan berkembang pesat dalam hal industri halal. Proyeksi tersebut didasarkan atas fakta Indonesia sebagai negara dengan mayoritas penduduknya beragama Islam. Di tahun 2020, jumlah penduduk muslim Indonesia mencapai 87,2 persen dari total populasi penduduk Indonesia. ${ }^{18}$ Sehingga sudah barang tentu, bahwa permintaan akan barang dan jasa halal di Indonesia sangat tinggi. Sehingga tidak salah jika dinilai bahwa Indonesia merupakan pasar yang besar bagi produk dan jasa halal.

Peningkatan dan perkembangan industri halal di Indonesia telah ditunjukkan dan diakui dalam skala global. Berdasarkan data yang dilansir dari Global Muslim Travel Index 2019, Indonesia menduduki 
peringkat pertama sebagai negara tujuan wisata halal dunia. ${ }^{19}$ Secara umum, di beberapa aspek industri halal global, Indonesia menduduki peringkat kelima sebagaimana dirilis dalam The State of Global Islamic Economy 2019-2020. Posisi tersebut naik dari peringkat kesepuluh di tahun $2018 .^{20}$ Dari beberapa capaian tersebut, Indonesia menargetkan untuk dapat menuju Global Hub Ekonomi Syariah. ${ }^{21}$

Secara regulasi dan pengelolaan terkait halal telah banyak dilakukan di Indonesia. Pengelolaan halal di Indonesia dilakukan dengan mengkolaborasikan beberapa aspek pengelolaan untuk pengembangan tata kelola halal. ${ }^{22}$ Aspek pengelolaan tersebut antara lain legislasi dan perundang-undangan, manajemen kontrol, laboratorium pemeriksa dan inspeksi halal, serta aspek edukasi dan sosialisasi kepada masyarakat. ${ }^{23}$ Beberapa diantaranya dengan membuat sertifikasi halal oleh LPPOM MUI, dan didukung juga dengan UU Jaminan Produk Halal. UU JPH tersebut tentu akan menguatkan pengembangkan produksi halal di Indonesia, yang akan sejalan dengan peningkatan konsumsi halal di Indonesia. Bahkan dengan adanya UU JPH tersebut diharapkan Indonesia dapat menjadi Halal Global Hub sebagaimana yang dicita-citakan.

Selain regulasi, pengelolaan aspek halal juga didukung dengan manajemen pengawasan dan kontrol kehalalan produk. Kontrol tersebut dimulai dari proses awal produksi, alat dan bahan produksi, audit dan dokumen, hingga produk yang dihasilkan. Selain itu, aspek pengawasan dengan didukung pengecekan dan tes laboratorium juga dilakukan. Hal tersebut sangat penting untuk dilakukan sehingga dapat menjamin kemungkinan adanya kontaminasi bahan produksi dari unsur-unsur yang diharamkan. ${ }^{24}$

Pengembangan pengelolaan halal di Indonesia, juga telah didukung penuh oleh lembaga dan institusi pendidikan. Hal tersebut sebagai upaya untuk mengedukasi dan sosialisasi kepada masyarakat terkait kehalalaln produk. Beberapa perguruan tinggi telah memiliki pusat kajian dan studi halal. Sehingga pusat kajian yang ada di lingkup perguruan 
tinggi tersebut dapat berperan sebagai agen bagi pemerintah dalam mengedukasi dan sosialisasi kepada masyarakat luas terkait pengelolaan halal di Indonesia.

Dalam penerapannya, pengembangan industri halal di Indonesia mencakup berbagai aspek. Qardhawi (1993) sebagaimana dikutip oleh Waharini \& Purwantini menjelaskan bahwa di dalam Islam halal tidak hanya berkaitan dengan kebendaan saja, melainkan juga aspek non kebendaan seperti perilaku dan perbuatan yang secara literatur fiqih dikenal dengan istilah muamalah. Dalam melakukan pengawasan terhadap kehalalan suatu produk, diperlukan pengawasan dari proses awal (input), proses setelah panen, pengemasan, hingga penyimpanan dan pendistribusian kepada konsumen. ${ }^{25}$ Semua harus mengikuti standar halal yang telah ditetapkan.

Saat ini industri halal terus mengalami pertumbuhan di beberapa sektor. Pertumbuhan tersebut antara lain terjadi pada sektor makanan dan minuman, travel dan wisata, fashion, obat-obatan dan kosmetik, media dan hiburan, hingga sistem keuangan. Tidak terkecuali pada sektor kesehatan dan pendidikan yang menjadi kebutuhan manusia. Komite Nasional Ekonomi dan Keuangan Syariah (KNEKS) menjelaskan berdasarkan data dari Indonesia Halal Lifestyle Center, bahwa industri halal Indonesia berpotensi memberikan dampak secara ekonomi terhadap produk domestik bruto nasional sebesar USD3.8 miliar. Angka tersebut diproyeksikan terus mengalami peningkatan hingga tahun 2025. ${ }^{26}$

Selain itu pengembangan industry halal juga akan meningkatkan produktivitas, baik di sektor riil juga di sektor keuangan. Dengan meningkatkan produksi halal di Indonesia, hal tersebut juga akan mendorong peningkatan sektor keuangan syariah di Indonesia, khususnya di sektor perbankan syariah. Karena aspek halal juga meliputi aspek permodalan dalam pengembangan usaha dan industri.

Merujuk kepada perkembangan dan pertumbuhan industri halal di Indonesia, Pemerintah telah menetapkan visi strategi nasional 
pengembangan industri halal dengan menjadikan industri halal dan ekonomi syariah sebagai penopang utama perekonomian nasional. ${ }^{27}$ Hal tersebut menargetkan upaya mewujudkan aspirasi bangsa sebagai negara yang berdaulat, mandiri, adil, makmur, dan madani. Visi tersebut diturunkan dalam penjabaran yang tertuang dalam misi dan strategi nasional dalam pengembangan industri halal. ${ }^{28}$ Salah satu strategi yang ditetapkan oleh Pemerintah Indonesia dalam mengembangkan industri halal adalah menciptakan UMKM berkualitas unggul yang dapat menghasilkan produk halal berstandar internasional dan keberlangsungan usaha dengan keuangan syariah. Hal ini menunjukkan bahwa pengembangan UMKM berbasis produk halal merupakan salah satu sasaran program Pemerintah yang perlu didukung dengan berbagai sumber daya dan sumber pendanaan yang dimiliki.

Salah satu langkah yang diterapkan dalam merealisasikan strategi tersebut adalah pada sektor pembiayaan syariah. Khususnya dalam aspek pembiayaan syariah non-bank, fintech syariah, hingga pembiayaan mikro syariah. Berangkat dari beberapa strategi pengembangan industri halal yang ditetapkan, sasaran yang ditargetkan oleh visi dan misi tersebut sejalan dengan maqashid dari wakaf, yang menargetkan kesejahteraan masyarakat.

\section{UMKM sebagai Pelaku Industri Halal}

UMKM merupaka salah satu kegiatan ekonomi produktif yang bertujuan untuk menumbuhkan usaha untuk berkontribusi aktif dalam mewujudkan pertumbuhan ekonomi nasional dengan asas demokrasi dan keadilan. Sehingga UMKM hadir untuk memberikan jawaban atas apa yang menjadi kebutuhan bagi masyarakat. Sehingga masyarakat Indonesia yang merupakan mayoritas penduduknya muslim memiliki tingkat permintaan akan produk dan jasa yang halal untuk dikonsumsi. Dengan begitu diharapkan UMKM hadir menjawab kebutuhan masyarakat Indonesia akan produk halal tersebut. 
UMKM merupakan salah satu pelaku di sektor industri halal. Bahkan pemerintah melalui strategi pengembangan industri halal KNEKS, menetapakan UMKM sebagai salah satu sasaran programnya. Sehingga upaya mendorong peningkatan UMKM akan berjalan beriringan dengan upaya mendorong peningkatan produksi halal. Karena salah satu yang mendorong pertumbuhan ekonomi adalah terdapat pada sektor riil, mulai dari skala mikro, kecil, hingga skala besar. Strategi pengembangan yang dicanangkan antara lain dalam hal digitalisasi ekonomi pada sektor UMKM, juga pembiayaan syariah, baik melalui lembaga bank maupun non bank. Selain itu, strategi tersebut juga diperkuat dengan program pembinaan usaha yang dijalankan oleh UMKM. ${ }^{29}$

Kekuatan UMKM dalam mengembangkan perekonomian di Indonesia telah terbukti. Sejak krisis melanda Indonesia pada 1998, UMKM telah berhasil menunjukkan ketahanannya di tengah goncangan krisis. $^{30}$ Kekuatan ini menunjukkan ketahanan sistem UMKM dalam membangun perekonomian di tengah masyarakat. Sistem yang terbangun di UMKM dengan gaya dan karakter yang khas dan dekat dengan kehidupan masyarakat, sehingga bisa memperkuat ikatannya dengan masyarakat. Sehingga UMKM terus didorong agar tumbuh berkembang di masyarakat.

Di sisi lain, belum masifnya pertumbuhan UMKM di Indonesia dilatarbelakangi oleh beberapa faktor. Beberapa faktor tersebut antara lain pendidikan pelaku UMKM. Selain itu, faktor gender juga menjadi salah satu penentu perkembangan UMKM. Sebuah survey menunjukkan bahwa bisnis yang dikelola oleh wanita lebih didominasi oleh dan terkonsentrasi ke bisnis tradisional dan pasar yang kurang dinamis. Peran UMKM di dalam perekonomian juga telah terbukti secara praktis. UMKM yang merupakan kegiatan padat karya, akan mampu meningkatkan lapangan pekerjaan. Semakin besar modal yang diinvestasikan kepada UMKM tersebut, maka akan tersedia semakin banyak lapangan pekerjaan. 
Salah satu kendala yang dihadapi pelaku usaha UMKM selain terkait akses permodalan, juga minimnya pengetahuan terkait pencatatan usaha yang dijalani. Tidak jarang dana yang seharusnya digunakan untuk modal usaha, terpaksa digunakan untuk memenuhi kebutuhan pribadi dan keluarga yang mendesak. Seperti halnya kebutuhan akan biaya sekolah anak, kebutuhan makan sehari-hari, hingga biaya sewa rumah dan lainnya. Kondisi ini tentu akan menghambat perkembangan usaha yang dijalaninya, karena dana yang seharusnya menjadi modal untuk pengembangan usaha, harus digunakan untuk keperluan lainnya yang lebih mendesak.

Selain kendala yang dihadapi, pelaku UMKM memiliki kelebihan yang sangat unik, khususnya terkait aspek halal. Dalam penelitian yang dilakukan oleh Qoyum \& Fauziyyah ditemukan bahwa pelaku UMKM khususnya di Yogyakarta mengedepankan aspek berkah yang diperoleh dari pembiayaan syariah. Sehingga keberkahan menjadi orientasi dan target pelaku UMKM dalam mendapatkan akses kepada pembiayaan ${ }^{31}$. Hal ini tentu sangat relevan dengan pengembangan industri halal yang juga menjadikan keberkahan sebagai orientasi dan target usaha yang dijalankan.

Selain itu, di balik kesulitan pelaku UMKM akan permodalan, terdapat sisi positif yang dimiliki. Dimana pelaku UMKM menggandeng lembaga keuangan mikro syariah untuk mendapatkan modal secara mudah. Dengan menggunakan skema kerja sama dan kemitraan, yang mewajibkan penerima modal untuk mengembalikan pokok modal dan bagi hasilnya. Hal ini yang menjadikan lembaga keuangan mikro syariah menjadi pilihan utama bagi pelaku UMKM. ${ }^{32}$

Beberapa langkah di atas menjelaskan bahwa UMKM yang kental dengan tradisi dan kemasyarakatan, lebih mengedepankan sisi kekeluargaan dan kesederhanaan. Selain itu aspek kehalalan dan keberkahan menjadi orientasi dari bisnis dan usaha yang yang dijalani. Sehingga proses produksi yang dilakukan, bahan baku, aspek 
pembiayaan, hingga output yang dihasilkan harus memenuhi ketentuan kehalalan sesuai prinsip Islam.

Adapun standar halal yang dimaksud adalah bahwa setiap proses produksi yang dijalankan sesuai dengan nilai dan prinsip Islam. Begitu juga dengan bahan baku hingga produk yang dihasilkan haruslah memenuhi unsur kemanfaatan dan maslahat (thoyyib). Sehingga rangkaian proses produksi hingga menghasilkan output merupakan proses yang menjaga kualitas. ${ }^{33}$ Indonesia sendiri, melalui Majelis Ulama Indonesia telah memiliki standar atas kehalalan suatu produk melalui suatu mekanisme verifikasi dan sertifikasi. Hal ini untuk menjamin bahwa proses produksi dan produk yang dihasilkan telah memenuhi unsur-unsur halal dan thayyib. ${ }^{34}$

\section{Pola Penyaluran Wakaf untuk Investasi dan Bisnis}

Pengelolaan wakaf memiliki peran penting dalam ketercapaian tujuan atau maqashid dari wakaf. Hingga kini, pengelolaan wakaf secara efisien masih menjadi salah satu tantangan utama yang dihadapi oleh nazhir wakaf. ${ }^{35}$ Dibutuhkan kompetensi yang mumpuni bagi para nazhir untuk dapat mengelola wakaf dengan baik, serta memberikan manfaat dan hasil yang berorientasi pada kemaslahatan umat. Pengelolaan tersebut mencakup pengumpulan wakaf, pendayagunaannya, serta penyaluran manfaatnya.

Secara prinsip, pengelolaan wakaf harus mengikuti ketentuan syariah dan regulasi yang berlaku. Hal ini dikarenakan wakaf merupakan bagian dari syariat Islam dimana segala hal terkait ketentuannya telah diatur di dalam alquran dan hadits, baik yang eksplisit maupun implisit. Dengan begitu seorang nazhir harus memahami ketentuan tersebut, agar dapat mengikuti prinsip pengelolaan wakaf dengan baik. Dengan kata lain bahwa pengelolaan wakaf harus diserahkan kepada nazhir yang berkompeten sehingga pengelolaan wakaf akan berjalan berdasarkan tata kelola yang baik dan profesional. ${ }^{36}$ 
Di dalam melakukan penghimpunan dan pengumpulan wakaf, nazhir harus mengukur kompetensi dirinya atas kemampuan mengelola aset wakafnya. Sehingga seorang nazhir yang memiliki keahlian di bidang pertanahan, tentu akan sangat relevan jika yang bersangkutan menghimpun aset wakaf berupa tanah. Begitu juga jika nazhir merupakan ahli di bidang pasar modal, sangat relevan jika nazhir tersebut menghimpun dan mengelola aset wakaf berupa saham atau surat berharga lainnya. Hal ini menjadi penting, agar pengelolaan wakaf bisa berjalan dengan baik, dan aset wakaf tetap utuh. ${ }^{37}$

Optimalisasi pengelolaan wakaf dimungkinkan untuk dilakukan dalam dua pola. Pertama, penyaluran wakaf melalui aset wakaf itu sendiri. Seperti halnya wakaf uang yang diterima oleh nazhir, maka uang yang merupakan aset wakaf tersebut disalurkan untuk diproduktifkan. Kedua, penyaluran wakaf melalui manfaat atau hasil dari pengembangan aset wakaf. Seperti tanah wakaf yang disewakan untuk parkir. Maka uang yang merupakan pendapatan dari penyewaan parkir yang akan disalurkan kepada mauquf 'alaih. ${ }^{38}$

Kedua pola tersebut tentu memiliki ketentuan masing-masing yang berlaku, baik ketentuan syariah maupun ketentuan operasional yang bergantung pada masing-masing nazhir. Titik persamaannya adalah bahwa kedua pola tersebut bermuara kepada tujuan yang sama, yaitu kemaslahatan umat. Artinya, kedua pola tersebut memiliki target satu yaitu maslahat masyarakat penerima manfaat wakaf ketika diimplementasikan.

Sejatinya wakaf dapat didayagunakan untuk investasi pada sektor bisnis dan komersial ataupun investasi pada infrastruktur yang menghasilkan laba. ${ }^{39}$ Pendayagunaan aset wakaf ini menjadi penting agar prinsip wakaf dengan menjaga pokok dan menyalurkan manfaatnya bisa lebih optimal. Dengan mengembangkan aset wakaf melalui investasi akan memberikan imbal hasil sehingga memiliki nilai lebih dan pertambahan pada aset wakaf itu sendiri. Dengan adanya penambahan 
hasil dari aset wakaf, maka prinsip pokok aset wakaf akan tetap utuh terjaga, sementara pendistribusian hasil akan lebih memberikan manfaat dan maslahat bagi masyarakat yang lebih luas. Untuk itu, upaya untuk mengembangkan aset wakaf terus dilakukan, baik melalui aset wakaf langsung seperti tanah dan lahan, maupun aset wakaf produktif, seperti uang atau surat berharga. Melalui aset wakaf langsung akan diupayakan untuk diproduktifkan sehingga memberikan manfaat yang lebih luas. Sedangkan aset wakaf produktif, akan tetap berlanjut dan terus dikembangkan saluran-saluran pengembangannya sebagai upaya memproduktifkan aset wakaf agar lebih optimal dan memberikan imbal hasil yang lebih.

Pengembangan aset wakaf dengan memproduktifkan aset tersebut, merupakan ikhtiar yang patut dijalankan oleh para nazhir wakaf. Untuk itu diperlukan kompetensi yang mumpuni dari para nazhir wakaf, agar aset wakaf dapat dikelola lebih optimal. Kompetensi ini sangat diperlukan agar proses pengembangan aset wakaf berjalan dengan baik, memberikan hasil dan manfaat lebih banyak, sehingga dapat memberikan maslahat lebih luas kepada masyarakat. Di samping itu, kompetensi nazhir dalam pengelolaan dan pengembangan aset wakaf sangat diperlukan untuk menghindari kerugian dalam pengelolaan aset wakaf, kerusakan secara fisik, atau pun bentuk kerugian lainnya. Dalam hal ini, untuk memitigasi resiko, pihak nazhir juga diperkenankan menggandeng pihak ketiga yang profesional untuk membantu dalam hal teknis pelaksanaan.

Optimalisasi pengelolaan wakaf saat ini banyak dilakukan melalui investasi pada infrastruktur pemerintah, infrastuktur umum, dan bahkan melalui skema-skema penyaluran bantuan dan pembiayaan usaha. Hal ini tentu tidak lepas dari maqashid wakaf untuk mensejahterakan masyarakat. Sehingga diharapkan melalui penyaluran manfaat wakaf kepada mauquf alaih akan dapat meningkatkan pendapatan dan kesejahteraan masyarakat luas. Selain itu, wakaf juga berperan dalam meningkatkan percepatan pembangunan melalui infrastuktur serta peningkatan struktur sosial di dalam proses pembangunan. Hal ini dapat dilakukan 
dengan memberdayakan wakaf sebagai penopang anggaran pemerintah dalam hal investasi infrastruktur dan pembangunan negara. ${ }^{40}$

Selain pengelolaan pada sektor investasi untuk infrastruktur, pengelolaan dan pengembangan aset wakaf juga dapat dilakukan melalui skema pembiayaan usaha masyarakat menengah ke bawah. Yaitu dengan menyasar para pelaku usaha yang memiliki kendala terkait akses permodalan dan perbankan. Dengan adanya penyaluran wakaf dalam skema ini, diharapkan kendala tersebut dapat teratasi. Di samping itu, pola ini juga melindungi masyarakat dari transaksi pinjaman ribawi yang ditawarkan oleh oknum masyarakat tertentu.

Pembiayaan melalui instrumen wakaf merupakan salah satu dari bentuk pengelolaan wakaf produktif. Skema tersebut dilakukan dengan memberikan dan menyalurkan manfaat wakaf melalui skema pembiayaan yang diberikan kepada mauquf alaih atau penerima manfaat wakaf. Penyaluran untuk pembiayaan ini dapat dilakukan dengan menyalurkan aset wakaf itu sendiri, maupun menyalurkan hasil/keuntungan dari pengelolaan aset wakaf. Dalam hal pengelolaan dan pembiayaan wakaf, baik untuk investasi maupun pada sektor bisnis komersial harus mengikuti prinsip syariah dalam setiap transaksinya, sebagaimana ketentuan yang berlaku pada transaksi di lembaga keuangan.

Dalam aspek pembiayaan, wakaf tunai memiliki kelebihan dalam fleksibilitas. Melalui mekanisme pembiayaan dengan akad yang sesuai dengan prinsip syariah, wakaf dapat mengurangi tingkat kemiskinan, serta mengatasi kesenjangan antara masyarakat kaya dan miskin. ${ }^{41}$ Meski demikian, penyaluran wakaf dalam pola pembiayaan harus tetap menjaga ketentuan dari ikrar wakaf. Sehingga tujuan wakaf yang diikrarkan wakif harus tetap dipenuhi sebagai bentuk amanah dalam pengelolaan wakaf. Di samping itu, terdapat beberapa poin yang perlu diperhatikan, seperti skala prioritas dalam pembiayaan, hingga manajemen resiko dalam penyaluran pembiayaan. Hal ini agar pengelolaan wakaf dapat terlaksana secara amanah. Terlebih jika yang disalurkan adalah aset 
wakaf itu sendiri, maka diperlukan pengelolaan resiko yang maksimal agar aset wakaf tetap terjaga dengan baik.

Pola yang memungkinkan dari penyaluran wakaf dalam bentuk pembiayaan adalah dengan menyalurkan manfaat atau hasil keuntungan dari pengelolaan aset wakaf. Hal ini lebih fleksibel bagi nazhir wakaf untuk menyalurkan pembiayaan kepada sektor komersial, khususnya pelaku usaha kecil yang sesuai dengan maqashid dari wakaf untuk mensejahterakan masyarakat. Pola pembiayaan tersebut dapat dilakukan dengan beberapa skema dan akad, seperti qardhul hasan, mudharabah, atau pun musyarakah. ${ }^{42}$

\section{Penyaluran Wakaf sebagai Instrumen Pembiayaan UMKM Halal}

UMKMyang bergerak pada industri atau produksi halal harus mencari sumber permodalan dari yang halal. Karena halal tidak hanya mencakup aspek produksinya saja, namun juga mencakup sumber permodalan. ${ }^{43}$ Namun tidak dipungkiri bahwa kendala umum yang dihadapi pelaku UMKM adalah akses permodalan kepada pihak perbankan. Hal ini lantaran terkendala masalah hal administratif secara umum. Kendala ini mengakibatkan sulitnya pelaku UMKM dalam mengembangkan usaha dan mencapai target pendapatan yang optimal.

Kendala administarasi dalam pengajuan pembiayaan untuk mendapatkan modal merupakan masalah utama yang dihadapi kebanyakan pelaku UMKM. Kondisi ini yang terkadang membuat pelaku bisnis kecil seperti UMKM beralih kepada sumber permodalan yang lebih menjanjikan secara administrasi, hingga mengesampikan aspek kehalalannya. Sumber permodalan tersebut baik diambil dari lembaga keuangan non bank, pinjaman online, hingga pinjaman individu seperti rentenir. Umumnya rentenir memberikan kemudahan dalam aspek persyaratan. Syarat tersebut hanya berupa KTP tanpa menetapkan syarat lainnya. Aspek kemudahan inilah yang mendorong sistem pinjaman renterir masih ada di masyarakat, dan cenderung lebih diminati. ${ }^{44}$ 
Sulitnya permodalan, khususnya akses perbankan, menjadi hambatan tersendiri bagi pelaku UMKM untuk mengembangkan bisnis yang dijalani. Kondisi tersebut jika dibiarkan berlanjut, tentu akan mengancam keberlangsungan usahanya hingga terancam bangkrut ataupun menghentikan proses produksi. Hal ini akan berdampak buruk kepada sektor lainnya, seperti penurunan tingkat produksi serta peningkatan jumlah pengangguran yang diakibatkan penghentian proses produksi. Kondisi tersebut sangat mungkin terjadi, karena ketika UMKM terkendala dalam permodalan, usaha yang dijalankan akan tidak optimal, sehingga proses produksi berjalan tidak maksimal. Dengan begitu tingkat produksi akan mengalami penurunan secara kuantitas maupun kualitas. Di sisi lain, ketika hal itu terjadi, maka tingkat pendapatan akan menurun. Hal ini menjadikan UMKM merumahkan para pekerjanya karena kesulitan untuk biaya operasional pegawainya. Sehingga angka pengangguran akan meningkat.

Merujuk kepada potensi dan peluang yang besar bagi pengembangan UMKM, kendala permodalan seharusnya tidaklah menjadi persoalan utama. Kendati demikian, diperlukan inovasi regulasi maupun kebijakan pihak yang terkait untuk memberikan solusi alternatif dalam menghadapi kendala tersebut. Diantaranya dengan memberikan akses permodalan alternatif bagi pelaku UMKM untuk mendorong pengembangan dan pertumbuhan UMKM. Permodalan yang memberikan kemudahan dari aspek administrasi maupun pencairan hingga pelaporannya.

Sebagai pelaku industri halal yang sangat dekat dengan masyarakat, UMKM diharapkan dapat diberikan akses modal dengan skema pembiayaan yang halal dan tidak menyalahi ketentuan syariah. Sehingga potensi UMKM dalam mengembangkan produk halal berbasis kedaerahan akan dapat dioptimalkan lebih baik, dengan tetap menjaga nilai dan prinsip kehalalannya.

Wakaf merupakan instrumen dalam ekonomi Islam yang ditujukan untuk mensejahterakan masyarakat. Karena wakaf merupakan ibadah 
yang mencakup dua aspek, yaitu hubungan manusia dengan Tuhannya, serta hubungan manusia dengan sesama manusia. ${ }^{45}$ Tujuan ini sejalan dengan tujuan yang disasar oleh UMKM yang menargetkan tujuan yang sama, dimana UMKM menjadi penyangga ekonomi, khususnya bagi masyarakat kecil. Eksistensi UMKM akan mendorong peningkatan produksi lokal dan juga membuka lapangan pekerjaan. Sehingga hal tersebut tentu akan memberikan kontribusi positif terhadap perekonomian bangsa.

Kendala permodalan yang dihadapi pelaku UMKM secara umum, sejatinya dapat diatasi melalui optimalisasi wakaf. Mekanisme tersebut dilakukan dengan tetap mengikuti aturan dan prinsip syariah sebagai pijakan utama dalam muamalah. Baik instrumen keuangan Islam seperti wakaf, maupun aspek kehalalan, keduanya memiliki kesamaan nilai dan prinsip. ${ }^{46} \mathrm{Di}$ antaranya dengan adanya ketentuan terkait skema akad dan transaksi yang sesuai dengan prinsip syariah, baik skema jual beli, sewa, atau pun penyertaaan modal.

Kesamaan tujuan dan target antara wakaf dan UMKM, sejatinya merupakan hal penting yang mampu mengintegrasikan wakaf dengan UMKM. Sehingga kesejahteraan masyarakat melalui instrumen wakaf akan dapat diwujudkan melalui penyalurannya kepada pelaku UMKM. Dengan demikian, wakaf sangat mungkin untuk difungsikan sebagai instrumen alternatif dalam pembiayaan atau permodalan bagi pelaku UMKM, yang mendukung sumber pembiayaan utama lainnya.

Sebagai pemegang amanah pengelolaan wakaf, nazhir wajib memperhatikan setiap aspek dalam pengelolaan dan pengembangan aset wakaf. Nazhir juga harus mengetahui dan memahami dengan baik, setiap pola transaksi yang dijalankan terkait aset wakafnya, agar aset wakaf tersebut tidak mengalami penurunan nilai maupun jumlahnya. Karena esensi dari wakaf adalah menjaga asalnya, dan menyalurkan manfaat dan hasilnya. Pola penyaluran wakaf, baik aset nya langsung ataupun dari hasil pengembangannya, perlu dilakukan secara pruden 
dan penuh kehati-hatian. Untuk itu, pihak nazhir diharapkan dapat berkolaborasi dan bersinergi dengan pelaku industri agar tercapai produktivitas yang optimal.

Sesuai dengan ketentuan dan karakateristik yang melekat pada wakaf, bisnis yang dapat menerima penyaluran wakaf utamanya adalah bisnis di skala kecil. Mengingat target dan maqashid dari wakaf adalah untuk mewujudkan kesejahteraan umat. Sehingga penyaluran wakaf kepada pelaku usaha kecil merupakan langkah konkrit dalam meningkatkan perekonomian masyarakat kecil. Selain itu, wakaf yang merupakan instrumen keuangan Islam, harus tetap berada pada koridor syariah. Dalam hal ini, jika wakaf disalurkan untuk membiayai suatu bisnis, maka bisnis tersebut harus sesuai dengan prinsip syariah. Hal ini yang juga merupakan karakteristik wakaf yang tidak bisa membiayai bisnis atau usaha yang diharamkan. Selain itu, penyaluran wakaf kepada pelaku bisnis juga harus memperhatikan akad yang sesuai dengan prinsip syariah.

Dengan menyesuaikan ketentuan dan karakteristik wakaf, maka UMKM produk halal sangat berpotensi dan dimungkinkan untuk menjadi pihak penerima wakaf. Hal ini tentu juga harus memperhatikan ikrar wakaf yang dilakukan oleh wakif saat penyerahan wakaf kepada nazhir.

Secara implementatif praktis, mekanisme operasional yang dapat dijalankan dalam dalam pembiayaan UMKM berbasis wakaf dapat direalisasikan dalam beberapa pola dan tahapan. Dalam hal pengelolaan wakaf tunai, pihak nazhir memiliki tanggung jawab penuh atas penilaian dan pemberian pertimbangan atas pola pembiayaan UMKM berbasis wakaf ini. Hal ini untuk menghindari hilangnya aset wakaf karena kegagalan usaha yang dijalankan oleh UMKM. Untuk itu nazhir wakaf diharuskan untuk memiliki kompetensi yang relevan untuk melakukan peninjauan pola pengelolaan wakaf uang tersebut. Hal itu dapat juga dilakukan dengan menggandeng pihak yang dianggap kompeten, yang 
sesuai dengan prinsip syariah. Pola dan tahapan pembiayaan UMKM berbasis wakaf ini dijalankan dengan penjabaran sebagai berikut:

Pertama, penyaluran manfaat atau keuntungan hasil pengembangan aset wakaf uang kepada pelaku UMKM sebagai penerima manfaat (mauquf 'alaih). Dalam mengimplementasikan penyaluran wakaf kepada pembiayaan UMKM, nazhir diharuskan menilai kesesuaian mekanisme tersebut dengan prinsip syariah. Beberapa ketentuan terkait penyaluran wakaf antara lain; 1) larangan untuk disalurkan kepada pembiayaan atas bisnis yang diharamkan, 2) pembiayaan yang diberikan melahirkan maslahat bagi masyarakat luas, serta 3) tidak melakukan pembiayaan dari hasil bisnis yang diharamkan. ${ }^{47}$

Berdasarkan beberapa ketentuan di atas diketahui bahwa wakaf dapat dioptimalkan melalui penyaluran kepada pelaku UMKM sebagai pihak penerima wakaf (mauquf'alaih). Hal tersebut dilakukan dengan memastikan bahwa bisnis dan usaha yang dijalankan UMKM penerima manfaat sesuai dengan prinsip syariah. Selain itu, perlu pula dipastikan bahwa akad yang dilakukan antara nazhir dengan pelaku UMKM sebagai penerima manfaat merupakan akad atau kontrak yang sesuai dengan prinsip syariah. Akad tersebut harus terbebas dari unsur riba, gharar, tadlis, maupun bentuk transaksi terlarang lainnya.

Dalam praktiknya penyaluran manfaat wakaf harus dilakukan dengan mengacu kepada setidaknya dua hal. Pertama, penyaluran manfaat hasil pengelolaan wakaf dilakukan sesuai dengan peruntukannya. Kedua, penyaluran manfaat wakaf dapat dilakukan secara langsung ataupun tidak langsung. Penyaluran secara langsung dilakukan dalam bentuk pembinaan dan pemberdayaan masyarakat yang dikelola oleh nazhir secara langsung. Adapun penyaluran tidak langsung dilakukan dalam bentuk pemberdayaan masyarakat melalui kemitraan dengan lembaga pemberdayaan lain yang memenuhi kriteria yang ditetapkan. ${ }^{48}$

Merujuk kepada ketentuan tersebut, maka penyaluran wakaf kepada pelaku UMKM harus dilakukan dengan memperhatikan aspek 
syariahnya. Sehingga penyaluran wakaf sebagai permodalan bagi UMKM akan dapat dilakukan jika telah dipastikan bahwa bisnis dan usaha yang dijalankan oleh UMKM memenuhi unsur kehalalan dan sesuai dengan prinsip syariah. Maka, hanya UMKM yang memproduksi produk halal saja yang dapat menerima pembiayaan dari dana wakaf. Selain halal, bisnis UMKM calon penerima pembiayaan dana wakaf juga harus memberikan manfaat dan maslahat bagi masyarakat luas, khususnya dalam hal pemenuhan kebutuhannya.

Kedua, penyaluran aset wakaf tunai dalam memberikan modal bagi pelaku UMKM secara langsung. Hal ini dilakukan dengan dasar bahwa aset wakaf tunai yang berupa uang dapat diinvestasikan pada sektor riil maupun sektor finansial ${ }^{49}$. Investasi dana wakaf tunai dapat dialokasikan, salah satunya pada sektor riil, yaitu kepada pelaku UMKM yang menjalankan prinsip syariah dan telah mengalami peningkatan secara skala usaha maupun pendapatannya. Dalam implementasinya, pola tersebut dapat dilakukan dengan skema bagi hasil, baik dengan akad mudharabah maupun musyarakah, ataupun akad lainnya yang relevan berdasarkan prinsip syariah. Pola ini dapat dilakukan dengan mempertimbangkan asas penjagaan kelestarian aset wakaf dan asas kesesuaian dengan prinsip syariah, baik dari segi akadnya, kehalalan usaha yang dijalankan produsen, hingga aspek pengelolaannya.

Berdasarkan ketentuan dalam Peraturan BWI No. 1 Tahun 2020, investasi dana wakaf tunai dilakukan baik secara langsung ataupun tidak langsung. Investasi secara langsung dilakukan jika telah memenuhi kriteria yang ditetapkan yaitu kesesuaian dengan prinsip syariah, pemenuhan syarat kelayakan, serta sumber pengembalian dapat dihitung berdasarkan studi kelayakan yang dilakukan. Hal ini mengindikasikan bahwa penyaluran aset wakaf tunai kepada pembiayaan UMKM Produk Halal dapat dilakukan dengan mengacu kepada hasil peninjauan yang dilakukan BWI terhadap aspek kelayakan. Hal ini menjadi salah satu hal utama di dalam menentukan UMKM penerima dana wakaf. Mengingat dana wakaf merupakan dana umat yang wajib dijaga keabadiannya, 
maka studi kelayakan kepada UMKM penerima sangat penting untuk dilakukan. Dengan demikian sasaran dan hikmah wakaf akan dapat terealisasi dengan mendorong pertumbuhan masyarakat secara ekonomi juga meningkatkan efektivitas pengelolaan dana wakaf untuk kemaslahatan umat.

Selain melakukan pembinaan dan pemberdayaan, nazhir wakaf juga memiliki tanggung jawab yang penting. Tanggung jawab tersebut dilakukan dalam bentuk pendampingan dan pembinaan kepada penerima wakaf, khususnya dalam memberikan akses modal usaha. Hal ini diharapkan dapat memacu pelaku UMKM sebagai penerima wakaf, dapat mengoptimalkan kinerja bisnis dan usahanya dengan memanfaatkan dana wakaf yang diterima. Untuk itu, diperlukan nazhir wakaf yang profesional untuk dapat melakukan pembinaan dan pendampingan usaha para pelaku UMKM yang menerima wakaf.

Dalam rangka meningkatkan transparansi pengelolaan wakaf, sebagaimana tertuang di dalam Peraturan BWI No. 1 Tahun 2020, disebutkan bahwa nazhir diwajibkan untuk melaporkan pengelolaan wakaf kepada BWI yang ditembuskan kepada Kementerian Agama RI melalui Direktorat Pemberdayaan Zakat dan Wakaf. Bahkan di dalam ketentuannya, BWI dapat memberikan sanksi administratif bagi nazhir yang tidak menyampaikan laporan pengelolaan wakafnya. Hal ini menunjukkan bahwa nazhir wakaf selain memiliki tanggung jawab penuh atas pengelolaan wakaf yang terhimpun, ia juga memiliki tanggung jawab atas pelaporan pengelolaannya. Hal ini merupakan salah satu bentuk pengawasan yang dilakukan kepada nazhir, agar pengelolaan wakaf dapat berjalan secara efektif, efisien, dan sesuai dengan prinsip dan ketentuan syariah.

\section{Kesimpulan}

Sebagai instrumen keuangan Islam, wakaf berorientasi pada kemaslahatan umat, khususnya untuk mensejahterakan masyarakat. Dengan karakteristik yang dimiliki, wakaf dapat lebih dioptimalkan 
untuk pengembangan sektor riil yang menjalankan roda perekonomian. Sektor riil yang mampu berdampak langsung kepada masyarakat, dari sisi distribusi pendapatan, mengurangi kesenjangan, hingga mengatasi pengangguran. Untuk itu, UMKM sebagai unsur sektor riil yang dapat memenuhi ketentuan tersebut, dapat dikembangkan melalui optimalisasi pendayagunaan wakaf. Dengan ketentuan dan prinsip syariah yang melekat pada wakaf, maka penyalurannya harus dilakukan kepada UMKM produk halal dan tidak bertentangan dengan prinsip syariah. Penyaluran wakaf kepada UMKM halal dilakukan dalam bentuk skema pembiayaan dan permodalan dengan memperhatikan kehalalan aspek bisnis yang dijalankan, serta akad yang diaplikasikan. Dengan begitu, diharapkan wakaf dapat berkontribusi aktif dalam pengembangan produk halal yang bermuara kepada kesejahteraan umat.

Berdasarkan kajian di atas, direkomendasikan bagi para nazhir wakaf untuk mengimplementasikan pendayagunaan hasil pengelolaan wakaf kepada pelaku UMKM di sektor produk halal melalui skema pembiayaan dan permodalan, dengan tetap memperhatikan ikrar wakaf yang dilakukan wakif. Selain itu, kajian ini juga merekomendasikan kepada Pemerintah untuk memberikan stimulus kebijakan terkait optimalisasi pengelolaan wakaf agar dapat diberdayakan lebih maksimal dalam meningkatkan pengembangan UMKM dan industri halal. Hal tersebut diharapkan dapat mendorong pengembangan optimalisasi wakaf yang sejalan dengan pengembangan industri halal dimana keduanya berorientasi kepada kesejahteraan umat. 


\section{Daftar Pustaka}

Ahmed, Umar, Omar M. Mustafa, and Ahamad Faosiy Ogunbado. "Examining the Traditional Waqf-Based Financing Methods and Their Implications on Socio-Economic Development." IOSR Journal of Business and Management (IOSR-JBM) 17, no. 2 (2015): 119-25. https://doi.org/10.9790/487X-17210106.

Aliasar, Afdhal. "Membangun Ketahanan Ekonomi Umat Melalui Industri Halal Indonesia." Jakarta, 2020.

Bank Indonesia, and Unair. Wakaf: Pengaturan Dan Tata Kelola Yang Efektif. Seri Ekonomi Dan Keuangan Syariah. Jakarta: Departemen Ekonomi dan Keuangan Syariah, Bank Indonesia, 2016.

BI, Departemen Ekonomi dan Keuangan Syariah. Usaha Mikro Islami. Jakarta: Bank Indonesia, 2016.

BPS. Potensi Peningkatan Kinerja Usaha Mikro Kecil. Jakarta: Badan Pusat Statistik, 2019.

CresentRating. “Global Muslim Travel Index 2019,” 2019.

“Data Populasi Penduduk Muslim 2020: Indonesia Terbesar Di Dunia." IBTimes.ID. 2020. https://ibtimes.id/data-populasi-pendudukmuslim-2020-indonesia-terbesar-di-dunia/\#: :text=Indonesia\%3A Negara dengan Populasi Muslim,yang berjumlah 263 juta jiwa.

DinarStandard. "State of The Global Islamic Economy Report 2019/20." Dubai, 2019.

Fahruroji. Wakaf Kontemporer. I. Jakarta: Badan Wakaf Indonesia, 2019.

Fuadi, Nasrul Fahmi Zaki. "Wakaf Sebagai Instrumen Ekonomi Pembangunan Islam." Economica: Jurnal Ekonomi Islam 9, no. 1 (2018): 151. https://doi.org/10.21580/economica.2018.9.1.2711.

Furqon, Ahmad. "Model-Model Pembiayaan Wakaf Tanah Produktif." 
Economica: Jurnal Ekonomi Islam 5, no. 1 (2016): 1. https://doi. org/10.21580/economica.2014.5.1.760.

Hadyantari, Faizatu Almas. "Pemberdayaan Wakaf Produktif : Upaya Strategis Untuk Kesejahteraan Ekonomi Masyarakat." Jurnal Middle East and Islamic Studies 5, no. 1 (2018).

Hudaefi, Fahmi Ali, and Irwandi Jaswir. "Halal Governance in Indonesia: Theory, Current Practices, and Related Issues." Journal of Islamic Monetary Economics and Finance 5, no. 1 (2019): 89-116. https://doi. org/10.21098/jimf.v5i1.1049.

Ibrahim Ahmed Khalil, Yunus Ali, and Mohammad Shaiban. “Waqf Fund Management in Kuwait And Egypt: Can Malaysia Learns from Their Experiences." In International Conference on Masjid, Zakat and Waqf (IMAF 2014), 69-83, 2014. http://www.kuis.edu.my/i-maf2014/ eproceedings/wakaf/W07 Ibrahim Khalil Waqaf 69-83.pdf.

Ismail, Abdul Ghafar, and Mohd Ali Mohd Noor. "Halal Finance and Halal Foods: Are They Falling Apart ?" Economica 12, no. 3 (2013): 113-26.

Jaffar, Mariatul Aida, and Rosidah Musa. "Determinants of Attitude towards Islamic Financing among Halal-Certified Micro and SMEs: A Preliminary Investigation." Procedia - Social and Behavioral Sciences 130 (2014): 135-44. https://doi.org/10.1016/j.sbspro.2014.04.017.

Jamal, Ahmad Muhammad Abdul Azim al. Daur Nizam Al Waqf Al Islamiy Fi at Tanmiyah Al Iqtishadiyyah Al Mu'ashirah. Kairo: Daar al Salam, 2007.

Kemenag. “Data Tanah Wakaf." Sistem Informasi Wakaf, 2020. http:// siwak.kemenag.go.id/.

Kemenkop UKM. “Perkembangan Data UMKM Dan UB Tahun 20172018," 2019. http://www.depkop.go.id/data-umkm.

Kementerian PPN/ Bappenas. "Indonesia Islamic Economic Masterplan 
2019-2024." Jakarta, 2019.

Mubarok, A Z S. “Literasi Wakaf Uang Berbasis Masjid: Literation of Cash Waqf Based On Mosque." Jurnal Bimas Islam 14, no. 1 (2021): 133-60. https://jurnalbimasislam.kemenag.go.id/jbi/article/view/355.

Nizar, Muhammad Afdi. "Munich Personal RePEc Archive Development of Productive Waqf in Indonesia: Potential and Problems." Munich Personal RePEc Archive, no. 97967 (2017). https://mpra.ub.unimuenchen.de/id/eprint/97967.

Nurdianto, Alfian Bayu. "Optimalisasi Wakaf Untuk Inkubator Bisnis Dan Teknologi Usaha Mikro Kecil Menengah (UMKM) Di Sidoarjo." Istismar: Jurnal Ekonomi Syariah 1, no. Januari (2019): 43-49.

"Potensi Aset Wakaf Capai Rp 2.000 Triliun per Tahun." Republika. September 2019. https://www.republika.co.id/berita/dunia-islam/ wakaf/19/09/30/pymexa383-bwi-potensi-aset-wakaf-capai-rp-2000triliun-per-tahun.

Qoyum, Abdul, and Neneng Ela Fauziyyah. “The Halal Aspect and Islamic Financing Among Micro, Small, and Medium Enterprises (MSMEs) in Yogyakarta: Does Berkah Matter?" Journal of Islamic Monetary Economics and Finance 5, no. 1 (2019): 215-36. https://doi. org/10.21098/jimf.v5i1.1055.

Rahman, Muh Idhiel Fitriawan, Nurwahidin Nurwahidin, and Naif Adnan. "Analisis Model Cash Waqf Linked Sukuk (CWLS) Sebagai Instrumen Pembiayaan Pemulihan Dampak Pandemi Covid-19." Jurnal Bimas Islam 14, no. 1 (2021): 77-102. https://doi.org/10.37302/ jbi.v14i1.343.

Rauf, Imam Abdur. Kitab Taysir Al Wuquf. 1st ed. Riyadh: Maktabah Nizar Mustafa al Baz, 1998.

Sabiq, Sayyid. Fiqih Sunnah. Jakarta: Pena Pundi Aksara, 2009.

Sabirin, Sabirin, and Dini Ayuning Sukimin. “Islamic Micro Finance 
Melati: Sebuah Upaya Penguatan Permodalan Bagi Pedagang Pasar Tradisional." Economica: Jurnal Ekonomi Islam 8, no. 1 (2017): 27. https://doi.org/10.21580/economica.2017.8.1.1824.

Shabana, Hasan. "Role of Waqf in Enhancing Muslim Small and Medium Enterprises (SMEs) in Singapore." In 8th International Conference on Islamic Economics and Finance, 1-50. Qatar: Qatar Foundation, 2011.

Syamsuri, Syamsuddin Arif, Alfarid Fedro, Vina Fithriana Wibisono, Veithzal Rivai, Iwan Kurniawan Subagja, and Salim Basalamah. "Existence of Waqf in Enhancing of Indonesia Financial Stability." East African Journal of Economics, Business, and Management 4464, no. 12 (2019): 744-53.

Traore, Ibrahima, Zunaidah Sulong, and Aminata Doukoure. "Conceptual Review for Cash Waqf Using Mudharabah Approach for Developing Public Employment Opportunity." J Halal Ind Serv 1, no. 1 (2018).

Waharini, Faqiatul Mariya, and Anissa Hakim Purwantini. "Model Pengembangan Industri Halal Food Di Indonesia." Muqtasid: Jurnal Ekonomi Dan Perbankan Syariah 9, no. 1 (2018): 1. https://doi. org/10.18326/muqtasid.v9i1.1-13.

Wahyudi, Dicky, Peny Cahaya Azwari, Achmad Alfajr, and Sandra Dhita Septiani. "Sinergitas Organisasi Publik Dengan Mengimplementasikan Sukuk Wakaf Melalui Pembentukan Halal Center Industry." In Simposium Nasional Keuangan Negara, 718-43. Jakarta: Badan Pendidikan dan Pelatihan Keuangan, Kemenkeu, 2018.

Yuli, Sri Budi Cantika. “Optimalisasi Peran Wakaf Dalam Pemberdayaan Usaha Mikro, Kecil Dan Menengah (Umkm)." Journal of Innovation in Business and Economics 6, no. 1 (2015): 1. https://doi.org/10.22219/ jibe.vol6.no1.1-16. 


\section{Endnotes}

1. BPS, Potensi Peningkatan Kinerja Usaha Mikro Kecil (Jakarta: Badan Pusat Statistik, 2019).

2. Kemenkop UKM, "Perkembangan Data UMKM Dan UB Tahun 2017-2018," 2019, http://www.depkop.go.id/data-umkm.

3. Departemen Ekonomi dan Keuangan Syariah BI, Usaha Mikro Islami (Jakarta: Bank Indonesia, 2016).

4. Nasrul FahmiZaki Fuadi, "WakafSebagai Instrumen Ekonomi Pembangunan Islam," Economica: Jurnal Ekonomi Islam 9, no. 1 (2018): 151, https://doi. org/10.21580/economica.2018.9.1.2711.

5. A Z S Mubarok, "Literasi Wakaf Uang Berbasis Masjid: Literation of Cash Waqf Based On Mosque," Jurnal Bimas Islam 14, no. 1 (2021): 133-60, https:// jurnalbimasislam.kemenag.go.id/jbi/article/view/355.

6. Kemenag, “Data Tanah Wakaf,” Sistem Informasi Wakaf, 2020, http://siwak. kemenag.go.id/.

7. Muh Idhiel Fitriawan Rahman, Nurwahidin Nurwahidin, and Naif Adnan, "Analisis Model Cash Waqf Linked Sukuk (CWLS) Sebagai Instrumen Pembiayaan Pemulihan Dampak Pandemi Covid-19," Jurnal Bimas Islam 14, no. 1 (2021): 77-102, https://doi.org/10.37302/jbi.v14i1.343.

8. Afdhal Aliasar, "Membangun Ketahanan Ekonomi Umat Melalui Industri Halal Indonesia" (Jakarta, 2020).

9. Faizatu Almas Hadyantari, "Pemberdayaan Wakaf Produktif: Upaya Strategis Untuk Kesejahteraan Ekonomi Masyarakat," Jurnal Middle East and Islamic Studies 5, no. 1 (2018).

10. Sri Budi Cantika Yuli, “Optimalisasi Peran Wakaf Dalam Pemberdayaan Usaha Mikro, Kecil Dan Menengah (Umkm)," Journal of Innovation in Business and Economics 6, no. 1 (2015): 1, https://doi.org/10.22219/jibe.vol6.no1.1-16.

11. Alfian Bayu Nurdianto, “Optimalisasi Wakaf Untuk Inkubator Bisnis Dan Teknologi Usaha Mikro Kecil Menengah (UMKM) Di Sidoarjo," Istismar: Jurnal Ekonomi Syariah 1, no. Januari (2019): 43-49.

12. Sayyid Sabiq, Fiqih Sunnah (Jakarta: Pena Pundi Aksara, 2009). 
13. Ahmad Muhammad Abdul Azim al Jamal, Daur Nizam Al Waqf Al Islamiy Fi at Tanmiyah Al Iqtishadiyyah Al Mu'ashirah (Kairo: Daar al Salam, 2007).

14. Imam Abdur Rauf, Kitab Taysir Al Wuquf, 1st ed. (Riyadh: Maktabah Nizar Mustafa al Baz, 1998).

15. Kemenag, "Data Tanah Wakaf."

16. Muhammad Afdi Nizar, "Munich Personal RePEc Archive Development of Productive Waqf in Indonesia: Potential and Problems," Munich Personal RePEc Archive, no. 97967 (2017), https://mpra.ub.uni-muenchen.de/id/ eprint/97967.

17. “Potensi Aset Wakaf Capai Rp 2.000 Triliun per Tahun,” Republika, September 2019, https://www.republika.co.id/berita/dunia-islam/wakaf/19/09/30/ pymexa383-bwi-potensi-aset-wakaf-capai-rp-2000-triliun-per-tahun.

18. “Data Populasi Penduduk Muslim 2020: Indonesia Terbesar Di Dunia," IBTimes.ID， 2020， https://ibtimes.id/data-populasi-penduduk-muslim2020-indonesia-terbesar-di-dunia/\#: :text=Indonesia\%3A Negara dengan Populasi Muslim,yang berjumlah 263 juta jiwa.

19. CresentRating, "Global Muslim Travel Index 2019," 2019.

20. DinarStandard, "State of The Global Islamic Economy Report 2019/20" (Dubai, 2019).

21. Aliasar, "Membangun Ketahanan Ekonomi Umat Melalui Industri Halal Indonesia."

22. Faqiatul Mariya Waharini and Anissa Hakim Purwantini, "Model Pengembangan Industri Halal Food Di Indonesia," Muqtasid: Jurnal Ekonomi Dan Perbankan Syariah 9, no. 1 (2018): 1, https://doi.org/10.18326/muqtasid. v9i1.1-13.

23. Fahmi Ali Hudaefi and Irwandi Jaswir, "Halal Governance in Indonesia: Theory, Current Practices, and Related Issues," Journal of Islamic Monetary Economics and Finance 5, no. 1 (2019): 89-116, https://doi.org/10.21098/jimf. v5i1.1049.

24. Waharini and Purwantini, "Model Pengembangan Industri Halal Food Di Indonesia." 
25. Waharini and Purwantini.

26. Aliasar, "Membangun Ketahanan Ekonomi Umat Melalui Industri Halal Indonesia."

27. Aliasar.

28. Kementerian PPN/ Bappenas, "Indonesia Islamic Economic Masterplan 2019-2024" (Jakarta, 2019).

29. Aliasar, "Membangun Ketahanan Ekonomi Umat Melalui Industri Halal Indonesia."

30. BI, Usaha Mikro Islami.

31. Abdul Qoyum and Neneng Ela Fauziyyah, "The Halal Aspect and Islamic Financing Among Micro, Small, and Medium Enterprises (MSMEs) in Yogyakarta: Does Berkah Matter?," Journal of Islamic Monetary Economics and Finance 5, no. 1 (2019): 215-36, https://doi.org/10.21098/jimf.v5i1.1055.

32. Sabirin Sabirin and Dini Ayuning Sukimin, "Islamic Micro Finance Melati: Sebuah Upaya Penguatan Permodalan Bagi Pedagang Pasar Tradisional," Economica: Jurnal Ekonomi Islam 8, no. 1 (2017): 27, https://doi.org/10.21580/ economica.2017.8.1.1824.

33. Abdul Ghafar Ismail and Mohd Ali Mohd Noor, "Halal Finance and Halal Foods: Are They Falling Apart ?," Economica 12, no. 3 (2013): 113-26.

34. Hudaefi and Jaswir, "Halal Governance in Indonesia: Theory, Current Practices, and Related Issues."

35. Ibrahim Ahmed Khalil, Yunus Ali, and Mohammad Shaiban, "Waqf Fund Management in Kuwait And Egypt: Can Malaysia Learns from Their Experiences," in International Conference on Masjid, Zakat and Waqf (IMAF 2014), 2014, 69-83, http://www.kuis.edu.my/i-maf2014/eproceedings/wakaf/ W07 Ibrahim Khalil Waqaf 69-83.pdf.

36. Umar Ahmed, Omar M. Mustafa, and Ahamad Faosiy Ogunbado, “Examining the Traditional Waqf-Based Financing Methods and Their Implications on Socio-Economic Development," IOSR Journal of Business and Management (IOSR-JBM) 17, no. 2 (2015): 119-25, https://doi.org/10.9790/487X-17210106.

37. Bank Indonesia and Unair, Wakaf: Pengaturan Dan Tata Kelola Yang Efektif, 
Seri Ekonomi Dan Keuangan Syariah (Jakarta: Departemen Ekonomi dan Keuangan Syariah, Bank Indonesia, 2016).

38. Bank Indonesia and Unair.

39. Dicky Wahyudi et al., "Sinergitas Organisasi Publik Dengan Mengimplementasikan Sukuk Wakaf Melalui Pembentukan Halal Center Industry," in Simposium Nasional Keuangan Negara (Jakarta: Badan Pendidikan dan Pelatihan Keuangan, Kemenkeu, 2018), 718-43.

40. Fuadi, "Wakaf Sebagai Instrumen Ekonomi Pembangunan Islam.”

41. Ibrahima Traore, Zunaidah Sulong, and Aminata Doukoure, "Conceptual Review for Cash Waqf Using Mudharabah Approach for Developing Public Employment Opportunity," J Halal Ind Serv 1, no. 1 (2018).

42. Hasan Shabana, "Role of Waqf in Enhancing Muslim Small and Medium Enterprises (SMEs) in Singapore," in 8th International Conference on Islamic Economics and Finance (Qatar: Qatar Foundation, 2011), 1-50.

43. Qoyum and Fauziyyah, "The Halal Aspect and Islamic Financing Among Micro, Small, and Medium Enterprises (MSMEs) in Yogyakarta: Does Berkah Matter?"

44. Sabirin and Sukimin, "Islamic Micro Finance Melati: Sebuah Upaya Penguatan Permodalan Bagi Pedagang Pasar Tradisional."

45. Syamsuri et al., "Existence of Waqf in Enhancing of Indonesia Financial Stability," East African Journal of Economics, Business, and Management 4464, no. 12 (2019): 744-53.

46. Mariatul Aida Jaffar and Rosidah Musa, "Determinants of Attitude towards Islamic Financing among Halal-Certified Micro and SMEs: A Preliminary Investigation," Procedia - Social and Behavioral Sciences 130 (2014): 135-44, https://doi.org/10.1016/j.sbspro.2014.04.017.

47. Ahmad Furqon, "Model-Model Pembiayaan Wakaf Tanah Produktif," Economica: Jurnal Ekonomi Islam 5, no. 1 (2016): 1, https://doi.org/10.21580/ economica.2014.5.1.760.

48. Fahruroji, Wakaf Kontemporer, I (Jakarta: Badan Wakaf Indonesia, 2019).

49. Fahruroji, 39. 